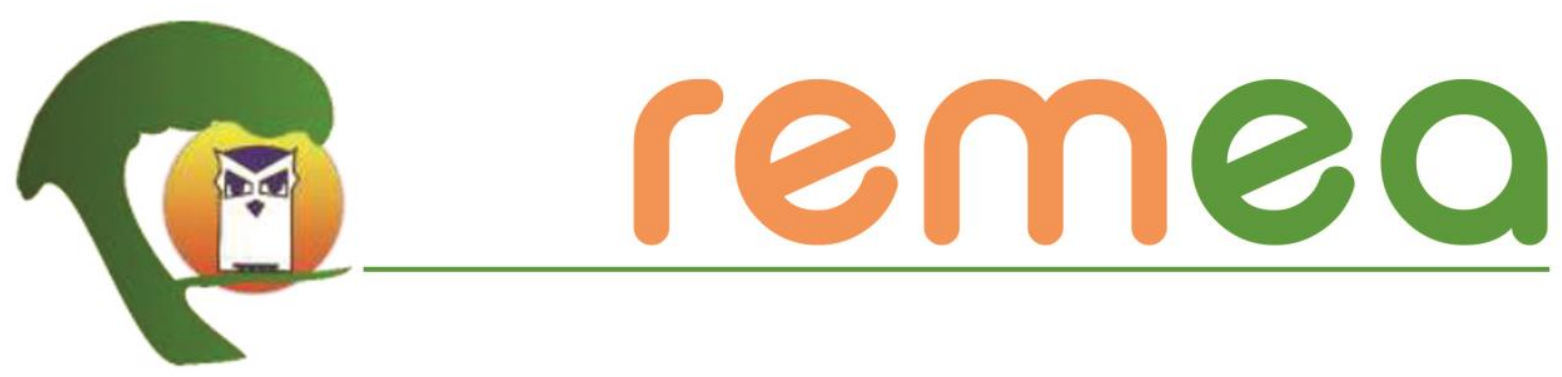

\title{
Resenha \\ Ideias para adiar o fim do mundo
}

Michel Mendes ${ }^{1}$

Universidade Federal de Goiás (UFG)

ORCID: $\underline{\text { https://orcid.org/0000-0003-0394-8086 }}$

KRENAK, Ailton. Ideias para adiar o mundo. 1. ed. São Paulo: Companhia das Letras, 2019.

Não é somente pelo título inquietante que Ailton Krenak chama a atenção. O autor, em 04 de setembro de 1987, durante a Assembleia Constituinte, fez um importante e forte discurso acerca dos direitos dos povos indígenas. Ao longo de seu curto discurso ${ }^{2}$ na tribuna, vestido em um terno branco, Krenak pinta seu rosto com tinta preta do jenipapo, como demarcação de uma cultura que vinha (e ainda vem) sendo negligenciada, não valorizada como constituinte primeira deste país e obrigada, a cada vez mais, ver seu território destruído e transformado, por exemplo, em áreas para a agricultura, mineração e/ou pecuária. Nitidamente em seu discurso, Krenak anuncia que uma população que vive em casas com telhados de palha e dorme em esteiras no chão, não representa uma ameaça aos interesses econômicos. Embora não anunciado em seu discurso, sabe-se que o modelo

\footnotetext{
${ }^{1}$ Professor no Programa de Pós-Graduação em Educação em Ciências e Matemática (PPGECM) da Universidade Federal de Goiás (UFG); Professor no Curso de Ciências Biológicas, modalidade Licenciatura, da UFG, vinculado ao Departamento de Educação em Ciências do Instituto de Ciências Biológicas. Doutor e Mestre em Educação pela Universidade de Caxias do Sul (UCS), Especialista em Gestão do Ensino Superior pela UCS, Licenciado e Bacharel em Ciências Biológicas pela UCS. E-mail: michel.mendes@ufg.br

${ }^{2}$ Pode ser conferido em: https://www.revistas.usp.br/gis/article/view/162846/157198. Acesso em: 18 mar. 2021.
}

Revista Eletrônica do Mestrado em Educação Ambiental Programa de Pós-Graduação em Educação Ambiental - FURG v. 38, n. 2, p. 8-14, mai./ago. 2021. E-ISSN: 1517-1256 
capitalista e a política brasileira, em especial a atual, evidenciam uma perspectiva inversa da defendida pelo autor.

Em Ideias para adiar o fim do mundo, publicado em 2019, produto de duas palestras, ambas proferidas em Lisboa em 2017 e 2019, e de uma entrevista também em Lisboa em 2017, o autor e líder indígena, ao longo de suas 72 páginas, critica a lógica cartesiana da dicotomização ser humano e natureza. Nascido na região do Vale do Rio Doce/MG, território do povo Krenak ${ }^{3}$, localidade devastada pelo crime da Empresa Samarco em 2015, Krenak situa sua crítica ao afirmar que uma "[...] humanidade que não reconhece que aquele rio que está em coma é também o nosso avô" (KRENAK, 2019, p. 47) reitera essa lógica que, ao mesmo tempo, é a premissa que origina o desastre socioambiental no Antropoceno, a atual proposta de nova Época ${ }^{4}$ geológica.

A obra está organizada em três partes, a saber: a primeira recebe o próprio nome da obra - "Ideias para adiar o fim do mundo"; a segunda - "Do sonho e da terra"; e a última - "A humanidade que pensamos ser". A seguir, apresentam-se alguns elementos do livro e seus diálogos com o campo da educação ambiental.

Na primeira parte do livro - "Ideias para adiar o fim do mundo" - Krenak inicia sua reflexão problematizando o entendimento de humanidade, pois aos olhos dos colonizadores, os brancos europeus eram dotados de uma humanidade que precisava ser compartilhada (e imposta) sobre aqueles que possuíam "humanidade obscurecida" (p. 11). Esse desejo em humanizar o mundo considerava uma noção de que existe uma maneira de ser e estar na Terra, indo de encontro aos costumes dos povos indígenas, por exemplo, que manifestavam posturas que precisavam ser guiadas por um modo iluminado de ser - eurocêntrico (e dualista: cultura $x$ natureza), mas que para ele, o autor, é incompatível com seu modo de ser e estar no mundo: “[...] fomos nos alienando desse organismo de que somos parte, a Terra, e passamos a pensar que ele é uma coisa e nós, outra: a Terra e a Humanidade. Eu não

\footnotetext{
3 "O nome Krenak é constituído por dois termos: um é a primeira partícula, kre, que significa cabeça, a outra, nak, significa terra. Krenak é a herança que recebemos dos nossos antepassados, das nossas memórias de origem, que nos identifica como 'cabeça da terra', como uma humanidade que não consegue se conceber sem essa conexão, sem essa profunda comunhão com a terra" (KRENAK, 2019, p. 48).

${ }^{4}$ Destaca-se que o autor não utiliza o termo Época, mas Era. Contudo, uma vez que o Antropoceno é uma proposição de Época geológica, essa é uma alteração conceitual importante a ser realizada.
} 
percebo onde tem alguma coisa que não seja natureza. Tudo é natureza. [...] Tudo em que eu consigo pensar é natureza" (KRENAK, 2019, p. 16-17).

Nesse sentido, segundo o autor:

\begin{abstract}
Como justificar que somos uma humanidade se mais de $70 \%$ estão totalmente alienados do mínimo exercício de ser? A modernização jogou essa gente do campo e da Floresta para viver em favelas e em periferias, para virar mão de obra em centros urbanos. Essas pessoas foram arrancadas de seus coletivos, de seus lugares de origem, e jogadas nesse liquidificador chamado humanidade. Se as pessoas não tiverem vínculos profundos com sua memória ancestral, com as referências que dão sustentação a uma identidade, vão ficar loucas neste mundo maluco que compartilhamos (KRENAK, 2019, p. 14).
\end{abstract}

Essa dinâmica humanizadora e agente de desenvolvimento/progresso, além de impregnar crenças e costumes estrangeiros, foi aos poucos sinalizando um modelo de bem-estar para o mundo, um padrão de vida, o que caracteriza as metrópoles como reproduções umas das outras. Com essa proposta, o distanciamento da terra é inevitável e louvável - uma "abstração civilizatória" (p. 22), abrindo espaço para a exploração desenfreada dos territórios tradicionais, anulando suas pluralidades e seus hábitos. Quem sobrou? "A sub-humanidade" (p. 21), os "quase-humanos" (p. 70), constituídos por uma "[...] camada mais bruta, rústica, orgânica [...] uma gente que fica agarrada na terra. [...]. A organicidade dessa gente é uma coisa que incomoda [...]" (p. 21-22), conforme destaca o autor:

Os únicos núcleos que ainda consideram que precisam ficar agarrados nessa terra são aqueles que ficaram meio esquecidos pelas bordas do planeta, nas margens dos rios, nas beiras dos oceanos, na África, na Ásia ou na América Latina. São caiçaras, índios, quilombolas, aborígenes - a sub-humanidade (KRENAK, 2019, p. 21).

Para Krenak, a principal marca do Antropoceno é a convicção humana a uma ideia estática de paisagem da Terra e de humanidade:

Nosso tempo é especialista em criar ausências: do sentido de viver em sociedade, do próprio sentido da experiência da vida. Isso gera uma intolerância muito grande com relação a quem ainda é capaz de experimentar o prazer de estar vivo, de dançar, de cantar. [...] A minha provocação sobre adiar o fim do mundo é exatamente sempre poder contar mais uma história. Se pudermos fazer isso, estaremos adiando o fim (KRENAK, 2019, p. 26-27, grifo nosso). 
A provocação que move o livro e que finaliza a primeira parte considera que ao contar histórias está se adiando o fim do mundo, pois significa romper com a dinâmica historicamente construída de distanciamento da natureza (herança da modernidade binômio ser humano-natureza) para viver momentos de circulação intensa pelo mundo, em conexão com os saberes tradicionais, mantendo "[...] nossas subjetividades, nossas visões, nossas poéticas sobre a existência" (p. 33). Implica "suspender o céu" (p. 32), ou seja, ampliar os horizontes existenciais, enriquecendo as subjetividades dos sujeitos que aceitam o convite do estar-com, e não contra, pois esse é um tesouro que os atuais tempos estão consumindo.

Em sua segunda parte - "Do sonho e da terra" - a obra aborda o difícil e complexo relacionamento histórico entre o estado brasileiro e as sociedades indígenas, no reconhecimento da legitimidade desses grupos em manter suas culturas e seus territórios: "o dilema político que ficou para as nossas comunidades que sobreviveram ao século XX é ainda precisar disputar os últimos redutos onde a natureza é próspera, onde podemos suprir as nossas necessidades alimentares e de moradia [...]" (KRENAK, 2019, p. 39-40). Ainda, segundo o autor, "o que está na base da história do nosso país, que continua a ser incapaz de acolher os seus habitantes originais [...] é a ideia de que os índios deveriam estar contribuindo para o sucesso de um projeto de exaustão da natureza" (KRENAK, 2019, p. 41).

A imposição histórica-colonial e o desejo (consumado) do modelo capitalista em transformar elementos naturais em recursos naturais, povos e territórios em escravos de uma matriz destrutiva ameaça não mais, e somente, as comunidades originárias, como também a todos que vivem na Terra. Para o japé yanomami, Davi Kopenawa, com quem Krenak dialoga em suas páginas, "[...] o mundo acredita que tudo é mercadoria, a ponto de projetar nela tudo o que somos capazes de experimentar" (KRENAK, 2019, p. 45). Ou seja, a demarcação do Antropoceno está impregnada da lógica/cultura do consumo, a exemplo da mercantilização e intoxicação do rio Doce, a quem os Krenak chamam de Watu (nosso avô uma pessoa), e não um recurso. Nessa esteira, o Antropoceno como fenômeno social de modificação dos ambientes terrestres e do funcionamento do sistema Terra (MENDES, 2019) precisa ser encarado como um alerta, segundo o autor, pois: 
[...] se nós imprimimos no planeta Terra uma marca tão pesada que até caracteriza uma era, que pode permanecer mesmo depois de já não estarmos aqui, pois estamos exaurindo as fontes da vida que nos possibilitam prosperar e sentir que estávamos em casa, sentir até, em alguns períodos, que tínhamos uma casa comum que podia ser cuidada por todos, é por estarmos mais uma vez diante do dilema a que já aludi: excluímos da vida, localmente, as formas de organização que não estão integradas ao mundo da mercadoria, pondo em risco todas as outras formas de viver - pelo menos as que fomos animados a pensar como possíveis, em que havia corresponsabilidade com os lugares onde vivemos e o respeito pelo direito à vida dos seres, e não só dessa abstração que nos permitimos constituir como uma humanidade, que exclui todas as outras e todos os outros seres (KRENAK, 2019, p. 46-47).

Diante disso, são evidentes os dilemas gerados pela crise civilizatória (LEFF, 2010), crise planetária (MORIN, 2015), as quais alertam para a necessidade de cosmovisões de respeito, de atos educativos pautados na emoção do amar (MATURANA, 2002), que é o reconhecimento do outro como legítimo outro na convivência, da negação da competição, que descaracteriza o humano (MATURANA, 2002). A educação ambiental, nesse contexto, como ato crítico-político de transformação social, convida e mobiliza ao processo de reconhecimento do mundo que é habitado, sendo que esse estado de coisas não é, mas está sendo (FREIRE, 1996). Logo, pode ser modificado.

Na última parte do livro - "A humanidade que pensamos ser" - o autor segue sua narrativa dando ênfase ao conceito de Antropoceno, que segundo ele "[...] tem um sentido incisivo sobre a nossa existência, a nossa experiência comum, a ideia do que é humano. $\mathrm{O}$ nosso apego a uma ideia fixa de paisagem da Terra e de humanidade é a marca mais profunda do Antropoceno" (KRENAK, 2019, p. 58). O clamor de Krenak é para não desistir e despertar, pois, inicialmente, os povos indígenas estavam ameaçados de vida ou de viver conforme os sentidos atribuídos por suas culturas. Agora, contudo, todos estão diante da Terra não suportar os vorazes desejos dos "grupos humanizados". Segundo ele, "o fim do mundo talvez seja uma breve interrupção de um estado de prazer extasiante que a gente não quer perder" (KRENAK, 2019, p. 60).

Para Krenak, pensar em um outro mundo significa imaginar uma reconfiguração das relações e dos espaços, em especial daquelas estabelecidas com a natureza. É aqui, sobretudo, que a educação ambiental encontra seu território de reflexão e ação, podendo,

Revista Eletrônica do Mestrado em Educação Ambiental Programa de Pós-Graduação em Educação Ambiental - FURG v. 38, n. 2, p. 8-14, mai./ago. 2021. E-ISSN: 1517-1256 
conforme Henning (2019, p. 765), “[...] contribuir com um olhar problematizador a respeito das nossas heranças". Afinal, "[...] o futuro do único lugar onde a vida é conhecida é determinado pelas ações dos seres humanos. No entanto, o poder que os humanos exercem é diferente de qualquer outra força da natureza, porque é reflexivo e, portanto, pode ser usado, retirado ou modificado" (LEWIS; MASLIN, 2015, p. 178; tradução e grifo nosso).

Para finalizar, nas palavras do autor, "não tem fim do mundo mais iminente do que quando você tem um mundo do lado de lá do muro e um do lado de cá, ambos tentando adivinhar o que o outro está fazendo" (KRENAK, 2019, p. 62). Diante das emergências construídas, alguns questionamentos para suscitar reflexões no campo da educação ambiental: "onde aterrar?"; "Devemos continuar alimentando grandes sonhos de evasão ou começamos a buscar um território que seja habitável para nós e nossos filhos?", questiona Latour (2020, p. 14-15); Rumo ao abismo ou rumo à metamorfose, uma outra ou nova via para o futuro da humanidade?, convites de Morin (2015); "Por que tanto medo assim de uma queda se a gente não fez nada nas outras eras senão cair?", indaga Krenak (2019, p. 62).

A partir disso, fica o convite ao leitor para que aprecie a obra de Ailton Krenak e para que se deixe provocar pelos questionamentos aventados.

\section{Referências}

FREIRE, Paulo. Pedagogia da autonomia: saberes necessários à prática educativa. São Paulo: Paz e Terra, 1996.

HENNING, Paula C. Resistir ao presente: tensionando heranças modernas para pensar a Educação Ambiental. Ciênc. Educ., Bauru, v. 25, n. 3, p. 763-781, 2019. Disponível em: https://www.scielo.br/pdf/ciedu/v25n3/1516-7313-ciedu-25-03-0763.pdf. Acesso em: 19 mar. 2021.

LATOUR, Bruno. Onde aterrar? Como se orientar politicamente no Antropoceno. 1. ed. Rio de Janeiro: Bazar do Tempo, 2020.

LEFF, Enrique. Epistemologia Ambiental. 5. ed. São Paulo: Cortez, 2010.

LEWIS, Simon L; MASLIN, Mark A. Defining the Anthropocene. Nature, 519, 171-180, 2015. Disponível em: https://www.nature.com/articles/nature14258. Acesso em: 12 jul. 2021. 
MATURANA, Humberto. Emoção e Linguagem na Educação e na Política. 3o reimp. Belo Horizonte: UFMG. 2002.

MENDES, Michel. A condição humana no Antropoceno: princípios educativos para horizontes legítimos de convivência. 2019. 111 f. Tese (Doutorado) - Programa de Pósgraduação em Educação, Área do Conhecimento de Humanidades. Universidade de Caxias do Sul, Caxias do Sul, 2019. Disponível em:

https://repositorio.ucs.br/xmlui/handle/11338/5110?locale-attribute=es. Acesso em: 12 jul. 2021.

MORIN, Edgar. A via para o futuro da humanidade. 2. ed. Rio de Janeiro: Bertrand Brasil, 2015.

Submetido em: 20-03-2021.

Publicado em: 20-08-2021. 